Research Article

\title{
Magnesium Enhances Osteogenesis of BMSCs by Tuning Osteoimmunomodulation
}

\author{
Xufang Zhang $\mathbb{D},{ }^{1}$ Qingpiao Chen, ${ }^{1}$ and Xueli Mao $\mathbb{D}^{2}$ \\ ${ }^{1}$ Department of Operative Dentistry and Endodontics, Guanghua School of Stomatology, \\ Guangdong Province Key Laboratory of Stomatology, Sun Yat-sen University, Guangzhou 510055, China \\ ${ }^{2}$ Department of General Dentistry and Oral Health, Guanghua School of Stomatology, \\ Guangdong Province Key Laboratory of Stomatology, Sun Yat-sen University, Guangzhou 510055, China \\ Correspondence should be addressed to Xueli Mao; maoxuel@mail.sysu.edu.cn
}

Received 13 June 2019; Accepted 17 October 2019; Published 14 November 2019

Guest Editor: Gongsheng Yuan

Copyright ( 2019 Xufang Zhang et al. This is an open access article distributed under the Creative Commons Attribution License, which permits unrestricted use, distribution, and reproduction in any medium, provided the original work is properly cited.

In the process of bone tissue engineering, the osteoimmunomodulatory property of biomaterials is very important for osteogenic differentiation of stem cells, which determines the outcome of bone regeneration. Magnesium $(\mathrm{Mg})$ is a biodegradable, biocompatible metal that has osteoconductive properties and has been regarded as a promising bone biomaterial. However, the high degradation rate of $\mathrm{Mg}$ leads to excessive inflammation, thereby restricting its application in bone tissue engineering. Importantly, different coatings or magnesium alloys have been utilized to lower the rate of degradation. In fact, a prior study proved that $\beta$-TCP coating of $\mathrm{Mg}$ scaffolds can modulate the osteoimmunomodulatory properties of $\mathrm{Mg}$-based biomaterials and create a favorable immune microenvironment for osteogenesis. However, the osteoimmunomodulatory properties of $\mathrm{Mg}$ ions themselves have not been explored yet. In this study, the osteoimmunomodulatory properties of $\mathrm{Mg}$ ions with involvement of macrophages and bone marrow stem cells (BMSCs) were systematically investigated. Microscale Mg ions $(100 \mathrm{mg} / \mathrm{L})$ were found to possess osteoimmunomodulatory properties that favor bone formation. Specifically, microscale $\mathrm{Mg}$ ions induced M2 phenotype changes of macrophages and the release of anti-inflammatory cytokines by inhibiting the TLR-NF- $\kappa$ B signaling pathway. Microscale Mg ions also stimulated the expression of osteoinductive molecules in macrophages while $\mathrm{Mg}$ ions/macrophage-conditioned medium promoted osteogenesis of BMSCs through the BMP/SMAD signaling pathway. These findings indicate that manipulating Mg ion concentration can endow the $\mathrm{Mg}$ biomaterial with favorable osteoimmunomodulatory properties, thereby providing fundamental evidence for improving and modifying the effect of Mg-based bone biomaterials.

\section{Introduction}

Foreign materials for repairing bone defects have a great influence on osteogenesis and osteoclasts, forming the basis for the study of osteoimmunology. Osteoimmunology aims to understand the interaction and related mechanism between the skeletal system and immune system [1]. When an implant is placed into a host, immune response around the implant is triggered. Following the start of immune response, phenotype switching of macrophages and adhesion of interleukin- (IL-) 10, IL-1ra, and other inflammatory factors occur, which also have an influence on cells associated with osteogenesis and osteoclasts $[1,2]$. As there is a strong relationship between the immune system and the skeletal system, an ideal bone biomaterial in the host should be able to accelerate osteogenesis in the bone defect area through local immune response. Immunomodulatory properties of bone substitute materials are suggested to be of great importance for the success of bone tissue engineering $[1,2]$.

Magnesium $(\mathrm{Mg})$ is an essential inorganic component in bone tissue and plays an important role in skeletal development. $\mathrm{Mg}$ has mechanical properties similar to those of bone tissue and displays antibacterial activity, excellent biocompatibility, and biodegradability $[3,4]$. Studies have shown that $\mathrm{Mg}$ ion supplementation improved the adhesion of osteoblasts to biomaterials, mediated by integrin [5]. In addition, $\mathrm{Mg}$ ions act as the nuclei for hydroxyapatite 
formation to promote bone matrix mineralization $[6,7]$. Mg-incorporation of mesoporous $\mathrm{TiO}_{2}$ coatings showed better surface, osteoconductive ability, and elevated expression of osteogenic genes [8]. However, there is still a great challenge that must be addressed before $\mathrm{Mg}$ can be utilized clinically. The active chemical character of $\mathrm{Mg}$ will not only produce a great amount of air, which reduces the contact between bone and material, but also result in an inflammatory reaction due to rapid degradation. Notably, different coatings or magnesium alloys have been utilized to lower the rate of degradation. A prior study showed that $\beta$-TCP coating of Mg scaffolds can modulate the scaffold's osteoimmunomodulatory properties and shift the immune microenvironment toward one that favors osteogenesis over osteoclastogenesis [9]. However, the osteoimmunomodulatory properties of $\mathrm{Mg}$ ion itself have not yet been explored.

Macrophages play an important role in human immune defense and osteoimmunology $[10,11]$. There are two typical phenotypes of macrophages. The classically activated M1 phenotype mainly participates in T helper cell 1- (Th1-) type inflammation, which is involved in defense against foreign harmful substances, but can sometimes cause excessive inflammatory response in host. Additionally, the alternatively activated M2 phenotype is involved in Th2-type inflammation which reduces inflammation response and improves impairment $[12,13]$. These two phenotypes can switch to each other in response to biomaterials or microbes. Furthermore, following phenotype switching of macrophages, osteoinductive molecules such as bone morphogenetic protein 2 (BMP-2) and transforming growth factor- $\beta$ (TGF- $\beta$ ) can be secreted to promote osteogenesis $[14,15]$. Given their important roles in bone remodeling, the response of macrophages was applied to evaluate the osteoimmunomodulatory properties of biomaterials [16].

In the present study, the osteoimmunomodulatory properties of microscale $\mathrm{Mg}$ ions were extensively investigated by using a biomimicking condition comprising $\mathrm{Mg}$ ions, bone marrow stem cells (BMSCs), and macrophages. First, the phenotype changes of macrophages in response to $\mathrm{Mg}$ ions and inflammatory/anti-inflammatory cytokines were evaluated to assess the immune environment. Thereafter, the important inflammatory signaling pathway factor, nuclear factor kappa B (NF- $\kappa \mathrm{B})$, was studied to explore the molecular mechanism of $\mathrm{Mg}$ ions in macrophages. The osteogenic differentiation of BMSCs mediated by the $\mathrm{Mg}$ ions was then investigated under the influence of macrophages, to prove whether the regulated immune environment by $\mathrm{Mg}$ ion could promote osteogenesis. The aim of this study was to determine whether microscale $\mathrm{Mg}$ ions possess osteoimmunomodulatory properties and whether this regulated immune environment could positively influence osteogenesis, ultimately providing the fundamental evidence of utilizing Mg-based biomaterial as bone scaffold.

\section{Materials and Methods}

2.1. Cell Culture. The murine-derived macrophage cell line, RAW 264.7 (RAW), was cultured in Dulbecco's modified Eagle Medium (DMEM, Gibco, USA) supplemented with
$10 \%$ heat inactivated fetal bovine serum (FBS, Gibco) and $1 \%(\mathrm{v} / \mathrm{v})$ penicillin/streptomycin (Sigma, USA) at $37^{\circ} \mathrm{C}$ in a humidified $\mathrm{CO}_{2}$ incubator. Growing cells were expanded for two passages before use in this study. Mice BMSCs were isolated and cultured following protocols from previous studies [9]. Bone marrow was briefly isolated from SD mice (5-6 weeks old). Under aseptic conditions, bilateral femurs and tibias of rats were isolated and removed. Bone marrow was rinsed with DMEM solution and centrifuged at $1000 \mathrm{rpm}$ for $5 \mathrm{~min}$. The supernatant was discarded, and the precipitate was resuspended with culture medium containing DMEM, 15\% FBS, and 1\% (v/v) penicillin/streptomycin. Cells were then seeded in tissue culture flasks and incubated at $37^{\circ} \mathrm{C}$ in a humidified $\mathrm{CO}_{2}$ incubator. The culture medium was first changed within $24 \mathrm{~h}$ and then every 3 days. The attached cells were expanded and early passages (p3) were used in the following study.

\subsection{Effect of Mg Ions on RAW264.7 Cells}

2.2.1. Proliferation of $R A W$ Cells Stimulated with Mg Ions. Cell culture medium consisted of DMEM without $\mathrm{Mg}$ ions (HyClone, USA), 10\% FBS, and 1\% (v/v) penicillin/ streptomycin. Based on the molecular weights of $\mathrm{Mg}$, $\mathrm{S}$, and $\mathrm{O}, \mathrm{MgSO}_{4}$ was added to the culture medium to a final concentration of $0,5,10,25,50,100,250$, and $500 \mathrm{mg} / \mathrm{L} \mathrm{Mg}$ ions. Additionally, the effects of $\mathrm{Mg}$ ions on RAW proliferation were investigated using Cell Counting Kit-8 Assay (CCK-8, Dojindo, Japan). RAW cells were seeded in 96-well microplates at a density of $2 \times 10^{3}$ cells/well and were allowed to adhere and spread for $24 \mathrm{~h}$. RAW cells were then treated with various concentrations of $\mathrm{Mg}$ ions $(0,5$, $10,25,50,100,250$, and $500 \mathrm{mg} / \mathrm{L}$ ) for 1,3 , and 7 days. Thereafter, cells were incubated with the CCK- 8 solution for $2 \mathrm{~h}$. The absorbance was measured at $450 \mathrm{~nm}$ by using a UV spectrophotometer.

2.2.2. Phenotype Switches and Expression of Inflammatory Genes in $R A W$ Cells. Gene expression of macrophage surface markers (CCR7 and CD206) and inflammatoryrelated cytokines (IL-1ra, IL-10, IL-1 $\beta$, IL-6, IL-18, and TNF- $\alpha$ ) were detected by RT-PCR to observe the phenotype changes and pro/anti-inflammation ability of RAW cells. These cells were also seeded on 6-well plates at a density of $1 \times 10^{6}$ cells/well. LPS $(1 \mu \mathrm{g} / \mathrm{mL})$ was added to the media when it reached $80 \%$ confluence to activate RAW cells for $2 \mathrm{~h}$. Cells were then stimulated with different concentrations of $\mathrm{Mg}$ ions $(0,10,100$, and $500 \mathrm{mg} / \mathrm{L})$ for $6 \mathrm{~h}$. Thereafter, total RNA was extracted by using TRIzol reagent (Invitrogen, USA), and the RNA concentrations were quantified with a Nanodrop protein/nucleic acid spectrophotometer (Thermo-Fisher, USA). Notably, first strand cDNA was synthesized using the RNA reverse transcription kit (Takara, Japan), and qRT-PCR was performed using a SYBR Green I Master kit (Takara) in LightCycle 96 RT-PCR (Roche, Switzerland). Primers for the target genes are listed in Table 1. 
TABle 1: Primer pairs used in the qRT-PCR.

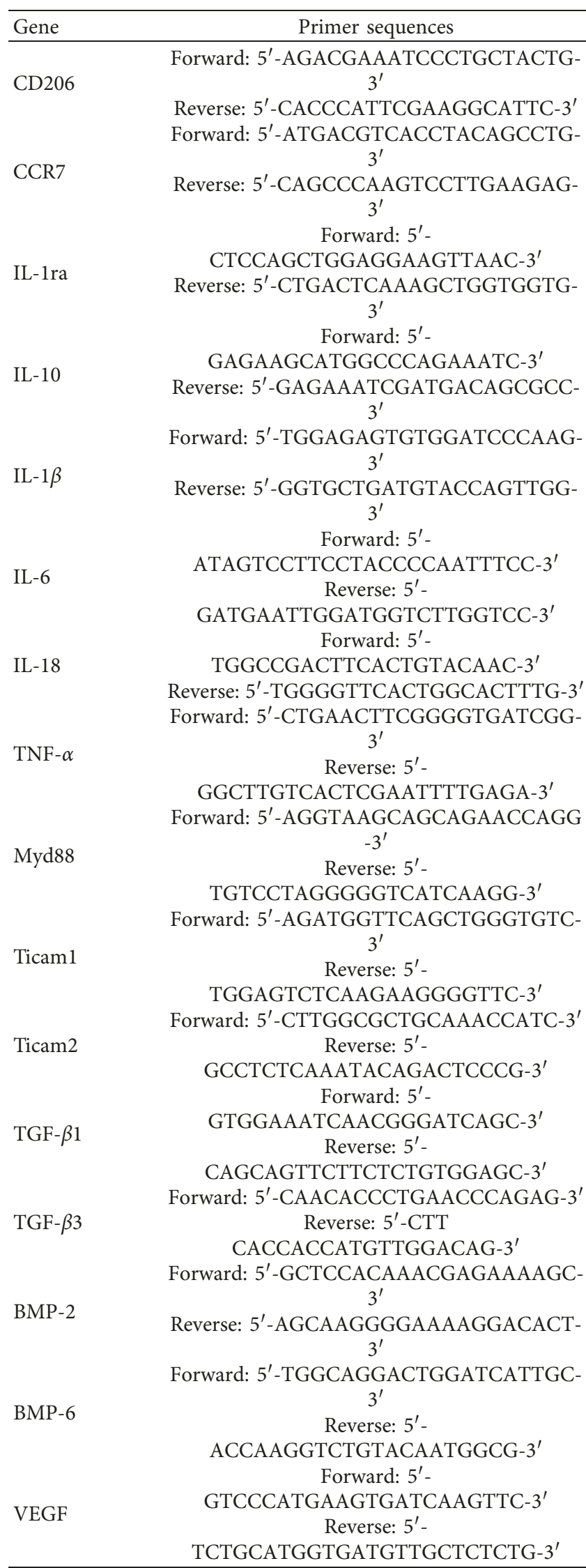

TABle 1: Continued.

\begin{tabular}{|c|c|}
\hline Gene & Primer sequences \\
\hline $\begin{array}{l}\text { GAPDH } \\
\text { (mouse) }\end{array}$ & $\begin{array}{c}\text { Forward: } 5^{\prime} \text {-TGACCACAGTCCATGCCATC- } \\
3^{\prime} \\
\text { Reverse: } 5^{\prime} \text {-GACGGACACATTGGGGGTAG- } \\
3^{\prime}\end{array}$ \\
\hline Runx-2 & $\begin{array}{c}\text { Forward: } 5^{\prime} \text {-TCTTTTGGGATCCGAGCACC- } \\
3^{\prime} \\
\text { Reverse: } 5^{\prime} \text {-ATCTCCACCATGGTGCGGTT-3' }\end{array}$ \\
\hline ALP & $\begin{array}{c}\text { Forward: } 5^{\prime} \text {-CCA TTT CAG CCT CAG GAT } \\
\text { CG-3' } \\
\text { Reverse: } 5^{\prime} \text {-TGG CCA CGT TGG TGT TGA } \\
\text { GT-3 }{ }^{\prime}\end{array}$ \\
\hline OPN & $\begin{array}{c}\text { Forward: } 5^{\prime} \text { - } \\
\text { CCAAGCGTGGAAACACACAGCC-3' } \\
\text { Reverse: } 5^{\prime}- \\
\text { GGCTTTGGAACTCGCCTGACTG-3' }\end{array}$ \\
\hline $\mathrm{OCN}$ & $\begin{array}{c}\text { Forward: } 5^{\prime} \text { - } \\
\text { GCCCTGACTGCATTCTGCCTCT-3' } \\
\text { Reverse: } 5^{\prime}- \\
\text { TCACCACCTTACTGCCCTCCTG-3' }\end{array}$ \\
\hline SMAD4 & $\begin{array}{l}\text { Forward: } 5^{\prime} \text { - TACCACCATAACAGCACTAC- } \\
3^{\prime} \\
\text { Reverse: } 5^{\prime} \text {-GAACACCAATATTCAGGAGC- } \\
3^{\prime}\end{array}$ \\
\hline SMAD5 & $\begin{array}{c}\text { Forward: } 5^{\prime}- \\
\text { GTACTATGAACTGAACAACGG-3' } \\
\text { Reverse: } 5^{\prime} \text {-TATAGATGGACACCTTTCCC-3' }\end{array}$ \\
\hline SMAD1 & $\begin{array}{c}\text { Forward: } 5^{\prime} \text { - } \\
\text { GAGATCAATAGAGGAGATGTTC -3' } \\
\text { Reverse: } 5^{\prime} \text {-TCGGTTCTTATTGTTGGAAG-3' }\end{array}$ \\
\hline BMPR1A & $\begin{array}{c}\text { Forward: } 5^{\prime} \text { - } \\
\text { GACACGTGCGAATTGGACAATG-3' } \\
\text { Reverse: } 5^{\prime} \text {-CGTCTGATTTCATACCAGTAC- } \\
3^{\prime}\end{array}$ \\
\hline GAPDH (rat) & $\begin{array}{l}\text { Forward: } 5^{\prime} \text {-TCAGCAATGCCTCCTGCAC-3' } \\
\text { Reverse: } 5^{\prime} \text {-TCTGGGTGGCAGTGATGGC-3' }\end{array}$ \\
\hline
\end{tabular}

2.2.3. Activation of Toll-Like Receptor (TLR) and NF- $\kappa B$ Signaling Pathways in RAW Cells. The TLR and NF- $\kappa \mathrm{B}$ pathways were analyzed to explore the molecular mechanisms that underlie the macrophage gene changes. RAW cells were seeded on 6-well plates at a density of $1 \times 10^{6}$ cells per well and grew to $80 \%$ confluence. RAW cells were first activated by LPS $(1 \mu \mathrm{g} / \mathrm{mL})$ for $2 \mathrm{~h}$ and then stimulated with different concentrations of $\mathrm{Mg}$ ions for $6 \mathrm{~h}$. Total RNA was collected for gene detection of myeloid differentiation factor 88 (MyD88) and TIR domain-containing adapter molecule 1 (Ticam1) and Ticam 2 by RT-PCR, using the same method described in Section 2.2.2.

Whole cell lysates were also collected after $6 \mathrm{~h}$ of stimulation by $\mathrm{Mg}$ ions, and protein expression of $\mathrm{NF}-\kappa \mathrm{B}$ p65 and inhibitor protein kappa B $(\mathrm{I}-\kappa \mathrm{B})$ were determined by western blot. In addition, total protein from RAW cells was extracted using the total protein extraction reagent kit (Beyotime Institute, Shanghai, China) and protein concentration was measured using the BCA assay. Equal amounts of protein $(20 \mu \mathrm{g})$ were prepared and separated using $10 \%$ sodium dodecyl sulphate polyacrylamide gel electrophoresis (SDS-PAGE) and then transferred onto 
PVDF membranes. Membranes were blocked in TBST containing $50 \mathrm{~g} / \mathrm{L}$ skim milk powder for $2 \mathrm{~h}$ and incubated with primary antibodies overnight at $4^{\circ} \mathrm{C}$. The primary antibodies included rabbit against mice anti-p-I- $\kappa \mathrm{B}$ polyclonal antibody (Bioss Corporation, Beijing, China), antiNF- $\kappa$ B p 65 monoclonal antibody (Santa Cruz, USA), and anti-GAPDH (Abcam, UK). Membranes were then washed 3 times and probed with the secondary antibody, anti-rabbit IgG (Bioteke Corporation, Beijing, China). The results were detected with the ECL detection kit, and the relative intensity of protein bands was quantified using the Image $J$ software. Levels of $\mathrm{I}-\kappa \mathrm{B}$ and NF- $\kappa \mathrm{B}$ expression were calculated relative to GADPH.

\subsubsection{Expression of Osteogenesis-Related Cytokines in RAW} Cells. RAW cells were seeded on 6-well plates, activated by LPS for $2 \mathrm{~h}$, and stimulated with different concentrations of $\mathrm{Mg}$ ions for $6 \mathrm{~h}$ as described in Section 2.2.3. Samples were collected and subjected to RT-PCR for the detection of BMP-2, BMP-6, TGF- $\beta 1$, TGF- $\beta 3$, and vascular endothelial growth factor (VEGF), using the method described in Section 2.2.2.

\subsection{Effects of Mg Ions/RAW Cells-Conditioned Media on the Osteogenic Differentiation of BMSCs}

2.3.1. ALP Activity Test. RAW cells were stimulated with different concentrations of $\mathrm{Mg}$ ions $(0,10,100$, and $500 \mathrm{mg}$ / L) for $6 \mathrm{~h}$. Culture media were then collected and marked as $\mathrm{Mg}$ ions/RAW264.7 cells-conditioned media. Alkaline phosphatase (ALP) activity of BMSCs in the condition medium was measured using the Alkaline Phosphatase Assay Kit (BioAssaySystems, USA). BMSCs were seeded on 24 -well plates at a density of $5 \times 10^{4}$ cells per well with the complete culture medium. After $80 \%$ confluence, cells were stimulated with $\mathrm{Mg}$ ions/RAW264.7 cells-conditioned media for 7 days. Cells were then lysed in 1\% Triton X-100. The supernatant of the medium was then harvested for ALP assay, and optical density (OD) was detected at $405 \mathrm{~nm}$ with a spectrophotometer. ALP activity is presented as OD values divided by the reaction time and total protein amount.

2.3.2. Osteogenic Gene Expression of BMSCs. BMSCs were seeded on 24 -well plates at a density of $5 \times 10^{4}$ cells per well with the complete culture medium. BMSCs were also stimulated with Mg ions/RAW264.7 cells-conditioned media for 1 day and 3 days. Samples were collected and subjected to RT-PCR for the detection of the osteogenic genes, Runx-2, ALP, OPN, and OCN, with the method described in Section 2.2.2.

2.3.3. Activation of BMP/SMAD Signaling Pathway in BMSCs. BMSCs were stimulated with Mg ions/RAW264.7 cells-conditioned media for 1 and 3 days, and total RNA was extracted to study the activation of BMP/SMAD pathway by RT-PCR as described in Section 2.2.2. Pathway-related genes included mothers against decapentaplegic homolog 1/4/5
(SMAD1/4/5) and bone morphogenetic protein receptor type IA (BMPR1A). Protein levels of SMAD4 and BMPR1A were further confirmed by western blot on days 3 and 7. The detailed methods are described in Section 2.2.3.

2.3.4. Statistical Analysis. All data were presented as mean \pm standard deviation (SD). Statistical analyses were performed with SPSS 22.0. One-way analysis of variance (ANOVA) was used to analyze the statistical difference when more than 2 groups were compared. Student's $t$-test was used to compare experimental groups and control group. A $P$ value $<0.05$ was considered to be statistically significant.

\section{Results}

3.1. Effect of $\mathrm{Mg}$ Ions on Cell Proliferation of Macrophages. To identify the cytotoxic effects of $\mathrm{Mg}$ ions, macrophages were treated with different concentrations of $\mathrm{Mg}$ ions $(5,10$, $25,50,250$, and $500 \mathrm{mg} / \mathrm{L}$ ) for 1,3 , and 5 days (Figure 1 ). The CCK- 8 assay showed that $100 \mathrm{mg} / \mathrm{L}(<100 \mathrm{mg} / \mathrm{L}) \mathrm{Mg}$ ions had no obvious influence on the proliferation of RAW264.7 cells compared to control $(P>0.05)$. However, $\mathrm{Mg}$ ions at a concentration of $100 \mathrm{mg} / \mathrm{L}$ significantly increased the proliferation of RAW264.7 on days 3 and $5(P<0.05)$. On day 5 , cell proliferation also significantly increased at a concentration of $250 \mathrm{mg} / \mathrm{L}(P<0.05)$.

3.2. Surface Marker Changes and Inflammatory Gene Expression of $R A W$ Cells in response to $M g$ Ions. Stimulation of RAW cells with $\mathrm{Mg}$ ions $(100 \mathrm{mg} / \mathrm{L})$ revealed the increased gene expression of the M2 surface marker, CD206, relative to the control group $(P<0.05$, Figure $2(\mathrm{a}))$, thereby indicating a shift toward the M2 phenotype in response to $\mathrm{Mg}$ ions. In contrast, stimulation with $\mathrm{Mg}$ ions resulted in reduced gene expression of the M1 phenotype marker, CCR7, compared to the control group $(P<0.05$, Figure $2(b))$.

The gene expression of anti-inflammatory and inflammatory cytokines was detected in RAW264.7 cells after exposure to $\mathrm{Mg}$ ions for $6 \mathrm{~h}$. The expression level of antiinflammatory genes (IL-10 and IL-1ra) was upregulated at all concentrations of $\mathrm{Mg}$ ions compared to the control $(P<0.05$, Figure 3(a)). In contrast, the expression of the inflammatory cytokine, TNF- $\alpha$, was significantly downregulated at concentrations of $10 \mathrm{mg} / \mathrm{L}$ and $100 \mathrm{mg} / \mathrm{L}$ of $\mathrm{Mg}$ ions $(P<0.05$, Figure $3(\mathrm{~b}))$. Furthermore, the expression of other inflammatory cytokines increased slightly. For instance, the expression of IL- 6 and IL- $1 \beta$ increased at $500 \mathrm{mg} /$ $\mathrm{L} \mathrm{Mg}$ ions and that of IL-18 increased at $10 \mathrm{mg} / \mathrm{L} \mathrm{Mg}$ ions $(P<0.05$, Figure 3(b)). However, the fold changes of inflammatory cytokines (IL-6, IL- $1 \beta$, and IL-18) were obviously less than that of anti-inflammatory cytokines (IL-10 and IL-1ra).

3.3. Effect of Mg Ions on TLRs and NF- $\kappa B$ Signaling Pathway in RAW 264.7 Cells. To explore the molecular mechanisms of the inflammation-related gene alterations, the TLRs and NF$\kappa \mathrm{B}$ signaling pathways were examined in RAW cells. 


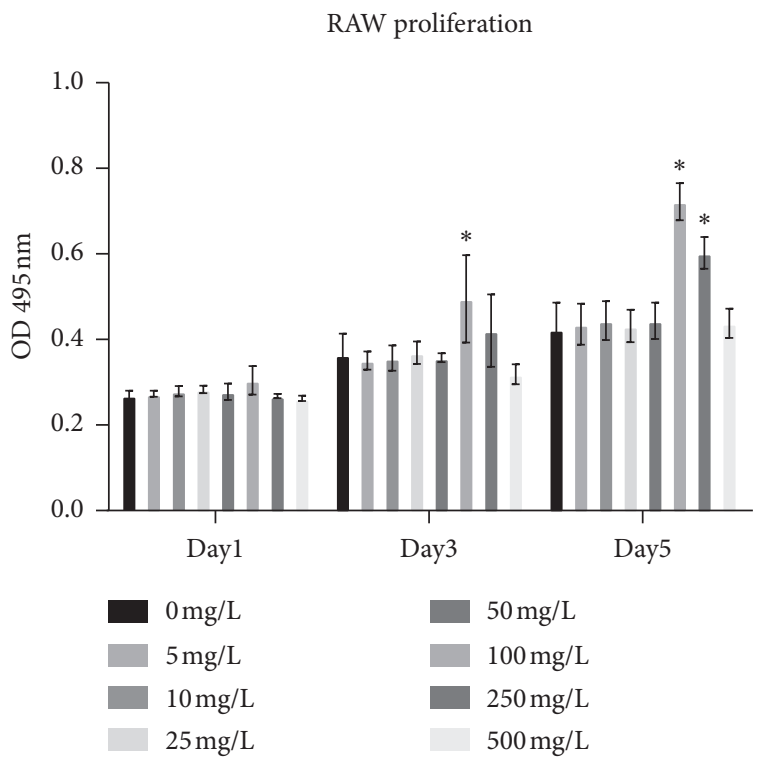

Figure 1: Effect of Mg ions on the proliferation of RAW264.7 cells. ${ }^{*} P<0.05$ versus the control without Mg ions.

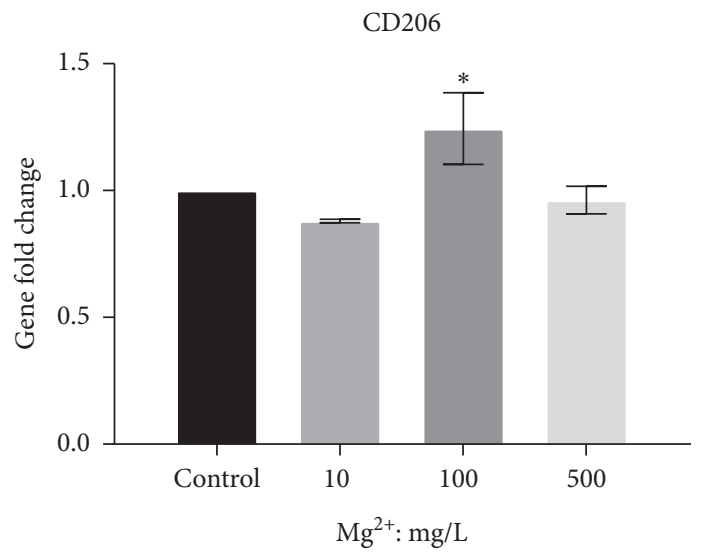

(a)

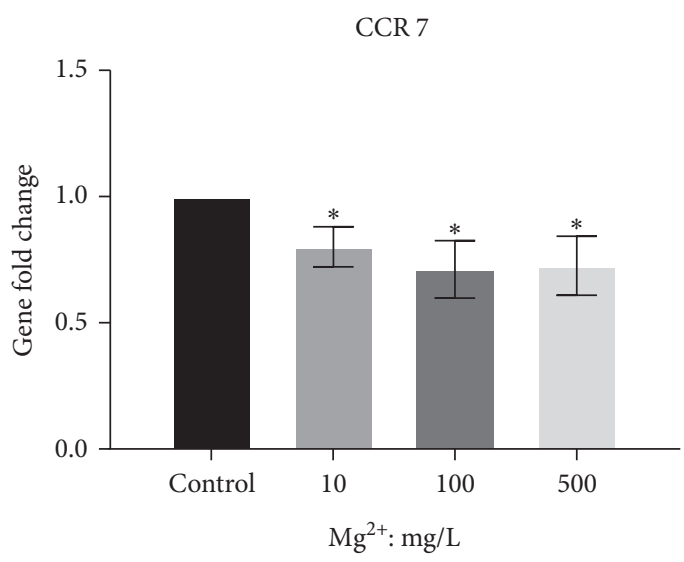

(b)

Figure 2: Effect of Mg ions on RAW264.7 phenotype transformation. (a) Gene expression of the M2 phenotype marker, CD206. (b) Gene expression of the M1 phenotype marker, CCR7. ${ }^{*} \mathrm{P}<0.05$, compared to the control group without $\mathrm{Mg}$ ions.
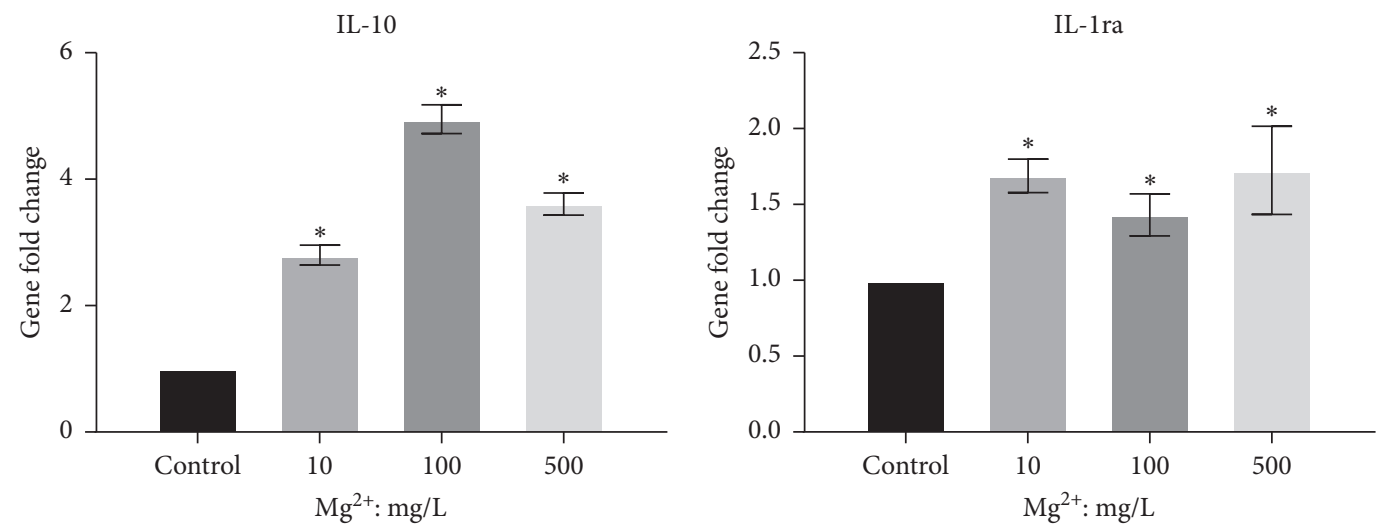

(a)

FIgURE 3: Continued. 

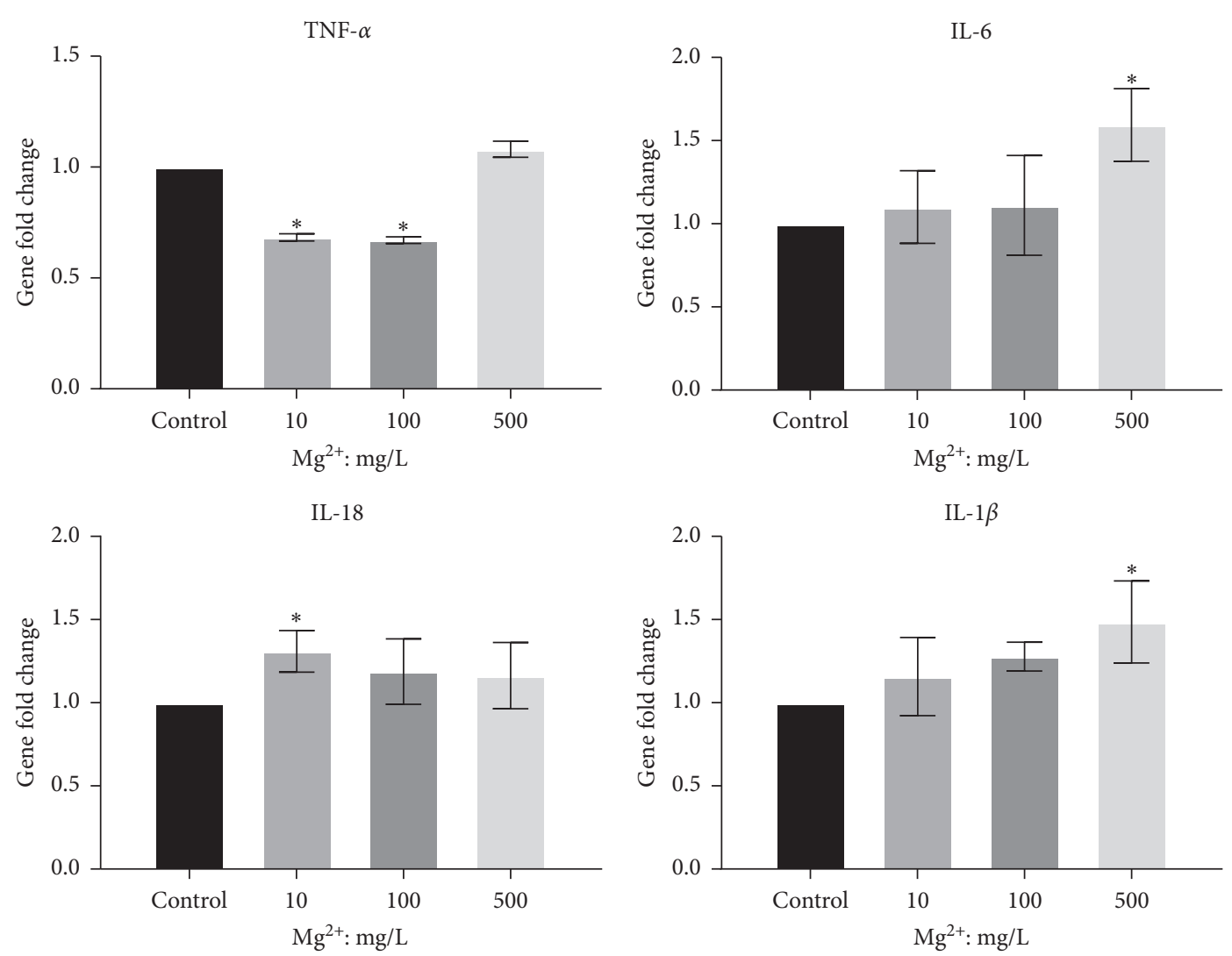

(b)

Figure 3: Effect of Mg ions on the gene expression of anti-inflammatory and inflammatory cytokines in RAW264.7 cells. (a) Gene expression of the anti-inflammatory cytokines, IL-10 and IL-1a. (b) Gene expression of the anti-inflammatory cytokines, TNF- $\alpha$, IL-6, IL-18, and IL- $1 \beta .{ }^{*} P<0.05$, compared to the control group without $\mathrm{Mg}$ ions.

Compared to the control group, gene expression of Myd88, Ticam 1 , and Ticam2 were downregulated in 100 and $500 \mathrm{mg} /$ $\mathrm{L} \mathrm{Mg}$ ion groups with significant differences $(P<0.05$, Figure 4(a)). Western blot also showed that the protein expression of NF- $\kappa \mathrm{B}$ p 65 had no significant difference between $\mathrm{Mg}$ ion and control groups. In contrast, the downstream molecular I $\kappa \mathrm{B}-\alpha$ was upregulated at 100 and $500 \mathrm{mg} /$ $\mathrm{L} \mathrm{Mg}$ ions compared to the control $(P<0.05$, Figure $4(\mathrm{~b}))$, indicating the inhibition of the TLR-NF- $\kappa \mathrm{B}$ signaling pathway.

3.4. Effect of $\mathrm{Mg}$ Ions on the Expression of OsteogenesisRelated Cytokines in RAW264.7 Cells. BMPs, the TGF- $\beta$ family, and VEGF are all important osteogenesis-related factors. RT-PCR demonstrated that gene levels of BMP-2 and VEGF were significantly higher in $100 \mathrm{mg} / \mathrm{L} \mathrm{Mg}$ ion groups than that of control $(P<0.05$, Figure 5$)$. In contrast, TGF- $\beta 3$ gene expression level was slightly downregulated in $\mathrm{Mg}$ ion groups compared to the control group $(P<0.05)$. Gene expression of TGF- $\beta 1$ and BMP- 6 showed no obvious differences in each group.

3.5. Effects of Mg Ions/RAW264.7 Cells-Conditioned Media on the Osteogenic Differentiation of BMSCs. To clarify whether $\mathrm{Mg}$ ions influence osteogenesis of BMSCs through regulating macrophages, $\mathrm{Mg}$ ions/RAW264.7 cells-conditioned media were utilized for osteogenic differentiation of BMSCs. The results showed that when BMSCs were stimulated with conditioned media containing 100 and $500 \mathrm{mg} / \mathrm{L}$ $\mathrm{Mg}$ ions, ALP activity was significantly enhanced compared to control $(P<0.05$, Figure $6(\mathrm{a}))$. Furthermore, osteogenic gene expression of BMSCs in conditioned media was explored by RT-PCR. On day 3, BMSCs stimulated with $\mathrm{Mg}$ ions/RAW264.7 cells-conditioned medium of all concentrations of $\mathrm{Mg}$ ions had a significantly upregulated expression of the osteogenic genes (Runx-2, ALP, OPN, and OCN) compared to the control group $(P<0.05$, Figure $6(b))$. In addition, on day 1 , conditioned medium with $100 \mathrm{mg} / \mathrm{L}$ $\mathrm{Mg}$ ions significantly increased gene expression of Runx-2, ALP, and OCN in BMSCs $(P<0.05$, Figure 6(b)).

3.6. Activation of the BMP/SMAD Signaling Pathway in BMSCs Stimulated with the Mg Ion/RAW264.7 Cells-Conditioned Media. To explore the molecular mechanisms of improved osteogenesis of BMSCs in Mg ions/RAW264.7 cells-conditioned media, the BMP/SMAD signaling pathway was studied. RT-PCR results showed that the gene expressions of SMAD4, SMAD5, and BMPR1A were increased significantly with all concentrations of $\mathrm{Mg}$ ions on day 3 $(P<0.05$, Figure 7(a)). Furthermore, on day 1 , the conditioned 


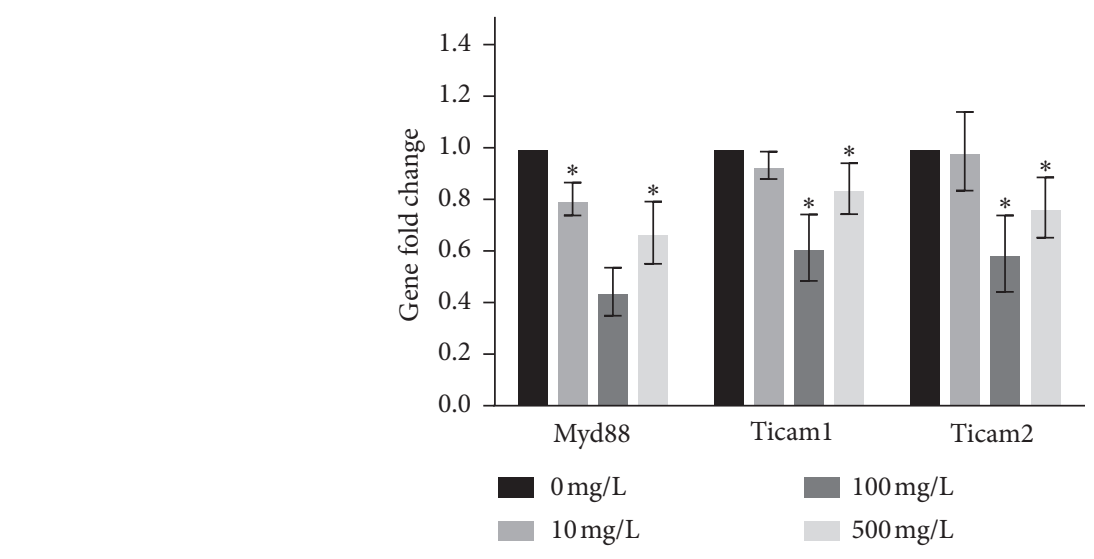

(a)
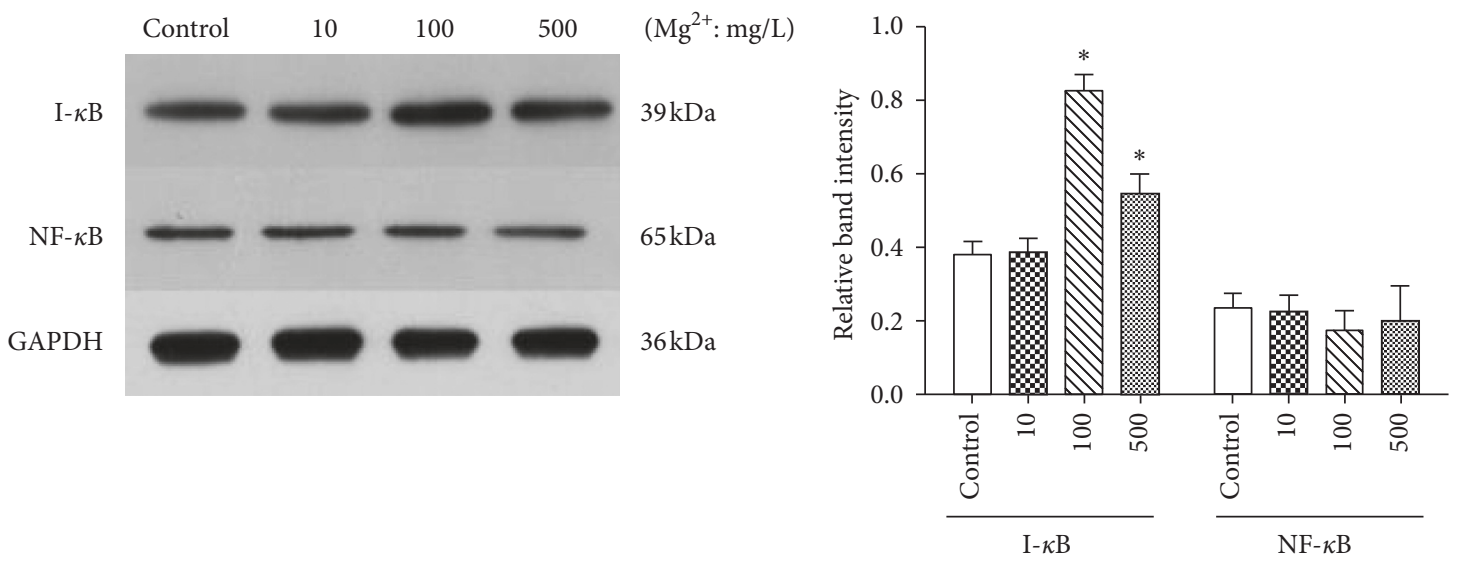

(b)

Figure 4: Effect of Mg ions on the TLR and NF- $\kappa$ B signaling pathways of RAW 264.7 cells. (a) Gene expression of the TLRs pathway markers, Myd88, Ticam1, and Ticam2 in RAW264.7 cells. (b) Protein expression of NF- $\kappa$ B p65 and I- $\kappa$ B in RAW 264.7 cells. ${ }^{*} P<0.05$, compared to the control group without $\mathrm{Mg}$ ions.

medium with $100 \mathrm{mg} / \mathrm{L} \mathrm{Mg}$ ions caused a significant increase in the gene expression of SMAD4 and BMPR1A $(P<0.05$, Figure $7(\mathrm{a})$ ). However, gene expression of SMAD1 had no obvious change in all groups. The protein expressions of SMAD4 and BMPR1A were further confirmed by western blot. The result showed that the protein levels of SMAD4 and BMPR1A significantly enhanced in the conditioned medium with 10 and $100 \mathrm{mg} / \mathrm{L} \mathrm{Mg}$ ions on day $3 \quad(P<0.05$, Figure 7(b)). However, on day 7, $100 \mathrm{mg} / \mathrm{L} \mathrm{Mg}$ ions/ RAW264.7 cells-conditioned media also significantly upregulated the protein expression of SMAD4 and BMPR1A $(P<0.05$, Figure $7(b))$.

\section{Discussion}

In this study, the osteoimmunomodulatory properties of $\mathrm{Mg}$ ions with the involvement of macrophages and BMSCs were systematically investigated. Our results showed that microscale $\mathrm{Mg}$ ions $(100 \mathrm{mg} / \mathrm{L})$ possess the osteoimmunomodulatory property that favors bone formation. More specifically, microscale $\mathrm{Mg}$ ions induced the M2 phenotype changes of macrophages and release of anti-inflammatory cytokines by inhibiting the TLR-NF- $\kappa$ B signaling pathway.
$\mathrm{Mg}$ ions stimulated the expression of osteoinductive molecules in macrophages, and $\mathrm{Mg}$ ions/macrophage-conditioned medium promoted osteogenesis of BMSCs, most likely through the BMP/SMAD signaling pathway. These findings indicated that manipulating $\mathrm{Mg}$ ion concentration can endow the Mg scaffold with favorable osteoimmunomodulatory properties, thereby providing the fundamental evidence for the development and modification of $\mathrm{Mg}$-based bone biomaterials.

$\mathrm{Mg}$ scaffold is a promising bone substitute due to its excellent mechanical properties and biocompatibility $[3,4,17]$. However, $\mathrm{Mg}$ is a highly reactive metal and corrodes quickly, thereby causing massive inflammatory reaction in vivo [6]. We inferred that the ionic concentration of the $\mathrm{Mg}$ scaffold is a key factor that determines the osteoimmunomodulatory property of biomaterials. However, a previous study showed that coating of the $\mathrm{Mg}$ scaffolds with $\beta$-TCP greatly decreased the concentration of $\mathrm{Mg}$ ions in solution $(195.4 \pm 0.86 \mathrm{mg} / \mathrm{L})$ compared to the $\mathrm{Mg}$ scaffolds $(1021 \pm 2.13 \mathrm{mg} / \mathrm{L})$ [9]. Mg- $\beta$-TCP scaffold has been proven to induce macrophages expressing the M2 surface marker, CD163, and anti-inflammatory cytokines (IL-1ra) [9]. Therefore, we hypothesized that the anti-inflammatory 

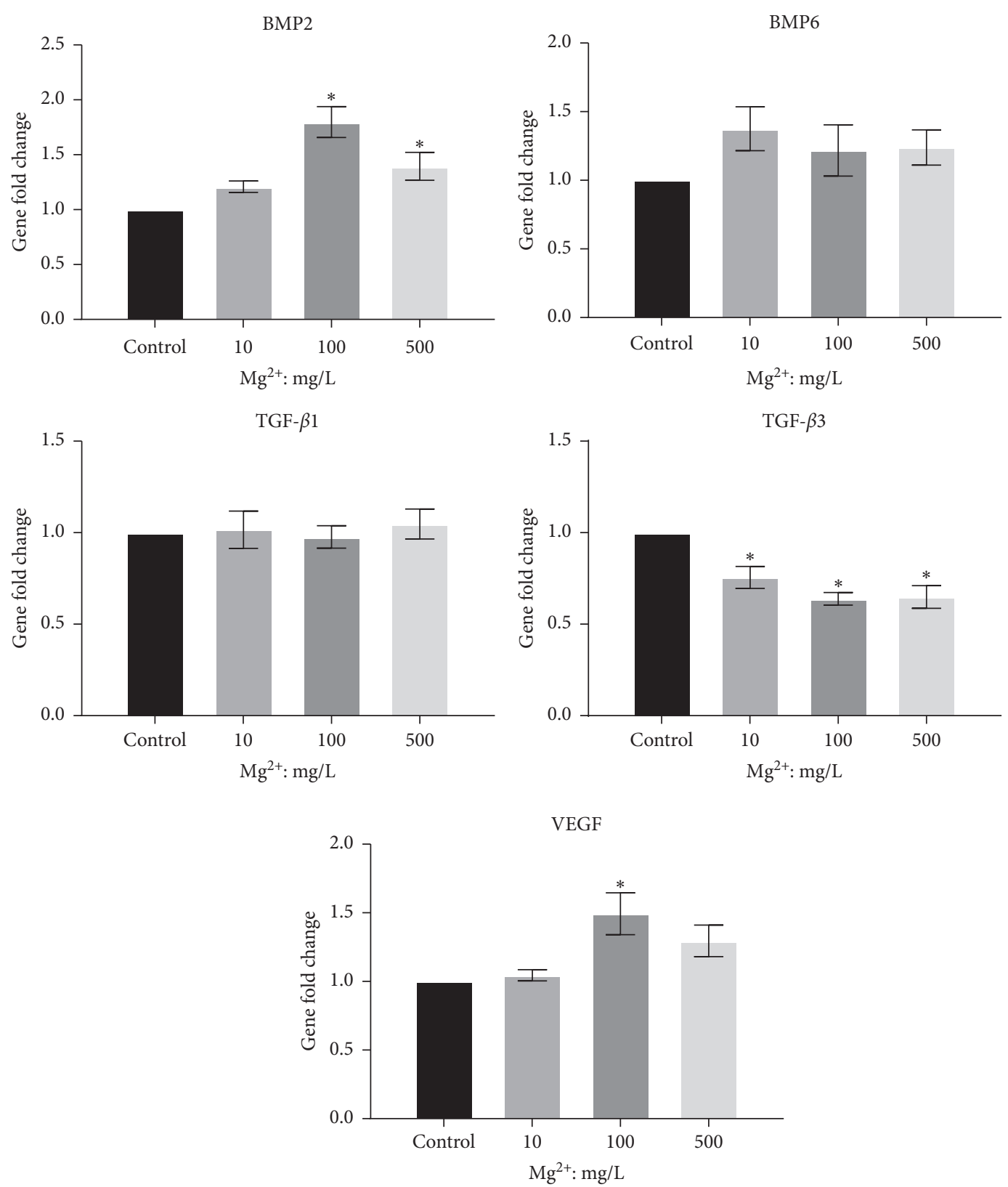

FIGURE 5: Effect of Mg ions on the gene expression of osteogenesis-related cytokines (BMP2, BMP6, TGF- $\beta 1$, TGF- $\beta 3$, and VEGF) in RAW264.7 cells. ${ }^{*} P<0.05$, compared to the control group without Mg ions.

effects of Mg- $\beta$-TCP are attributed to the lower concentration of $\mathrm{Mg}$ ions. Our present study however demonstrated that microscale $\mathrm{Mg}$ ions $(100 \mathrm{mg} / \mathrm{L})$ induce a shift toward the M2 phenotype of macrophage with increased gene expression of the surface marker, CD206, and reduced the M1 phenotype marker, CCR7. Microscale $\mathrm{Mg}$ ions $(100 \mathrm{mg} / \mathrm{L})$ also increased the gene expression of the anti-inflammatory cytokines, IL-10 and IL-1ra, and decreased the important inflammatory cytokine, TNF- $\alpha$. Although the inflammatory cytokines of IL- 6 and IL- $1 \beta$ increased slightly, it most likely occurred with the high concentration of $\mathrm{Mg}$ ions $(500 \mathrm{mg} / \mathrm{L})$. Consistently, a previous study by Sugimoto et al. showed that $\mathrm{MgSO}_{4}$ at a concentration of $60 \mathrm{mg} / \mathrm{L}$ decreased inflammatory cytokine production of IL- 6 and TNF- $\alpha$ by inhibiting the TLR receptor pathway [18], which is approximately the same concentration of $\mathrm{Mg}$ ion used in our study $(100 \mathrm{mg} / \mathrm{L})$. These findings indicate that the microscale $\mathrm{Mg}$ ions can induce macrophage polarization toward the M2 extremity and create an anti-inflammatory microenvironment for bone regeneration.

Notably, toll-like receptor (TLR) signaling is an essential pathway in the innate immune response, through which macrophages recognize foreign antibody and initiate antigen-specific adaptive immune response [19, 20]. Activation of TLR signaling is mediated by a unique interaction between TIR domain-containing cytosolic adapters which include MyD88 and TIR domain-containing adapter-inducing IFNb (TRIF) also known as toll-like receptor adapter 


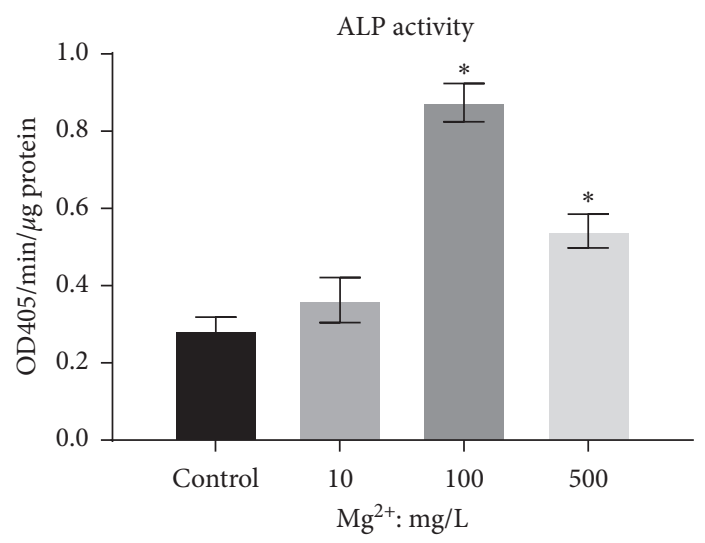

(a)
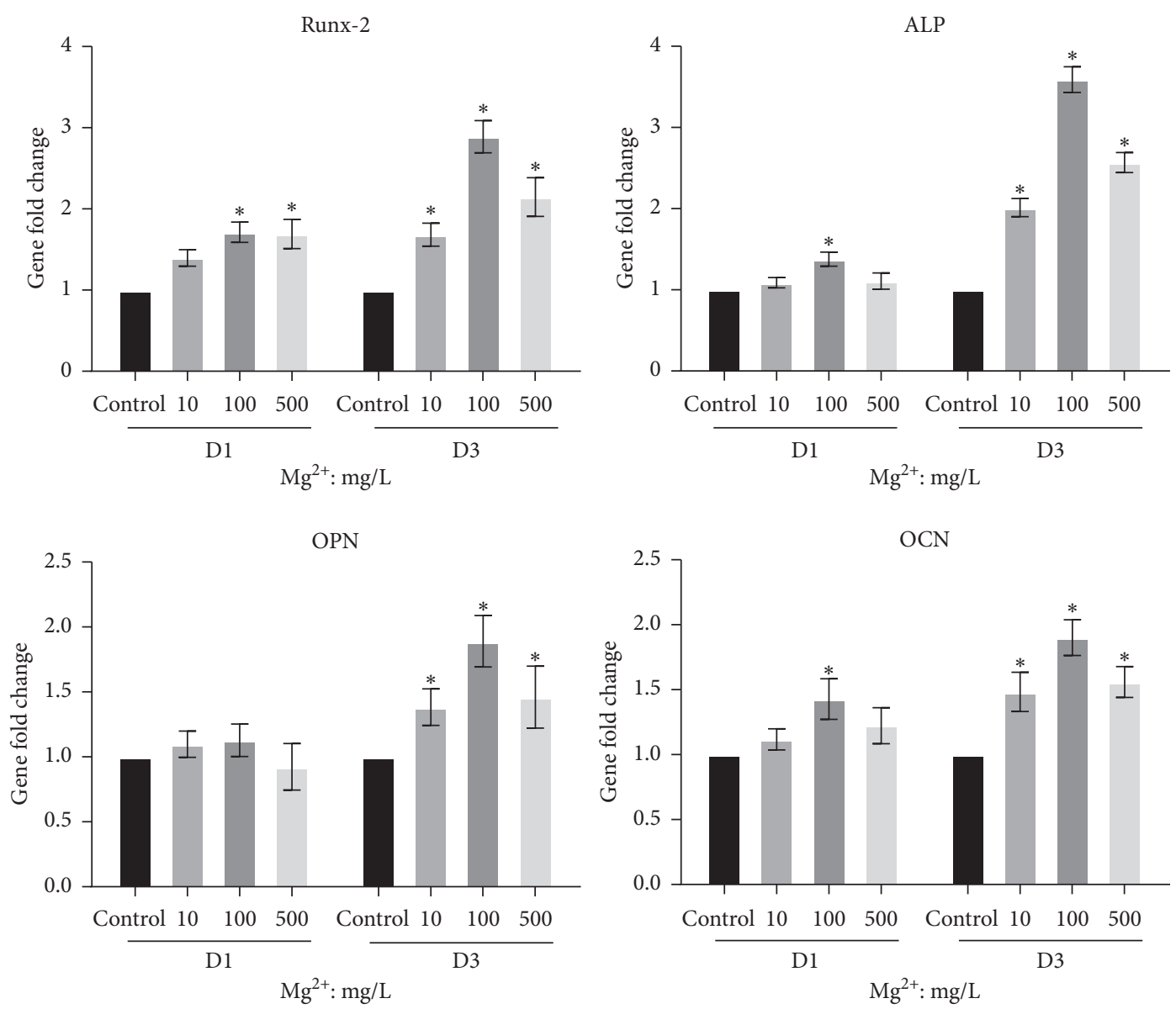

(b)

FiguRE 6: Effects of Mg ions/RAW264.7 cells-conditioned media on the osteogenic differentiation of BMSCs. (a) ALP activity of BMSCs in Mg ions/RAW264.7 cells-conditioned media. (b) Osteogenic gene expression of BMSCs in Mg ions/RAW264.7 cells-conditioned media. ${ }^{*} P<0.05$, compared to the control group.

molecule (Ticam) [20]. Importantly, upon ligand binding, TLR leads to the activation of NF- $\kappa \mathrm{B}$ pathways to elicit the expression of inflammatory cytokines [21]. In most cell types, NF- $\kappa \mathrm{B}$ is bound to its inhibitor, I- $\kappa \mathrm{B}$, and resides in the cytoplasm as an inactive NF- $\kappa \mathrm{B} / \mathrm{I}-\kappa \mathrm{B}$ complex [22]. However, the activated form of NF- $\kappa \mathrm{B}$ is a heterodimer of the p65 subunit associated with p50 or p52 subunit, and p65/ p50 or p65/p52 heterodimer migrates into the nucleus and initiates transcription of the inflammatory genes [22]. In the present study, the gene expression of Myd88, Ticam1, and Ticam 2 were downregulated and the NF- $\kappa$ B inhibitor, I $\kappa \mathrm{B}-\alpha$, was upregulated in the 100 and $500 \mathrm{mg} / \mathrm{L} \mathrm{Mg}$ ion groups. Such finding would indicate that the microscale $\mathrm{Mg}$ ions dampen the inflammatory response potentially by inhibiting the TLR-NF- $\kappa$ B pathway. Similarly, a previous study by Sugimoto et al. showed that $\mathrm{MgSO}_{4}$ decreases TLR-mediated 

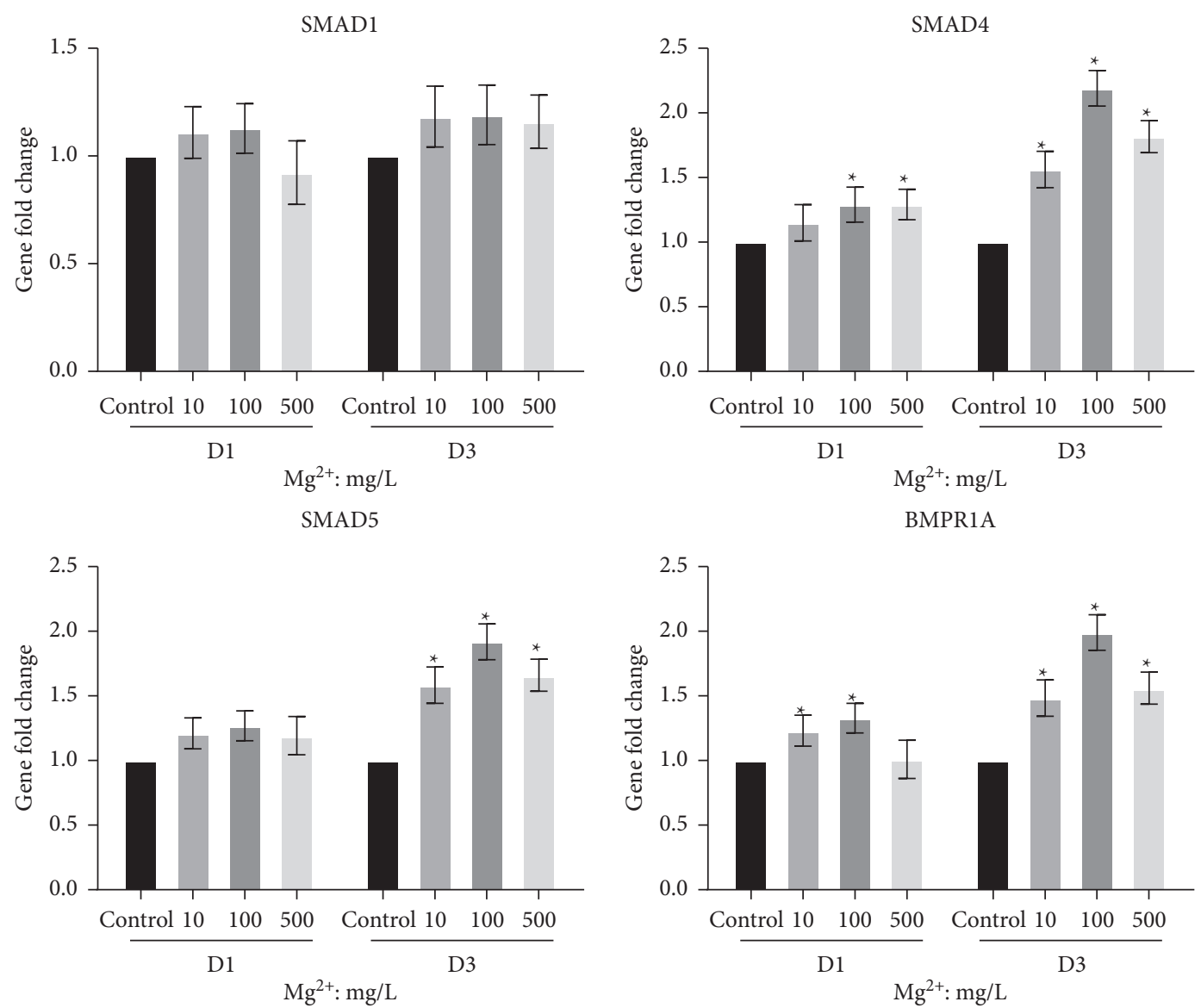

(a)

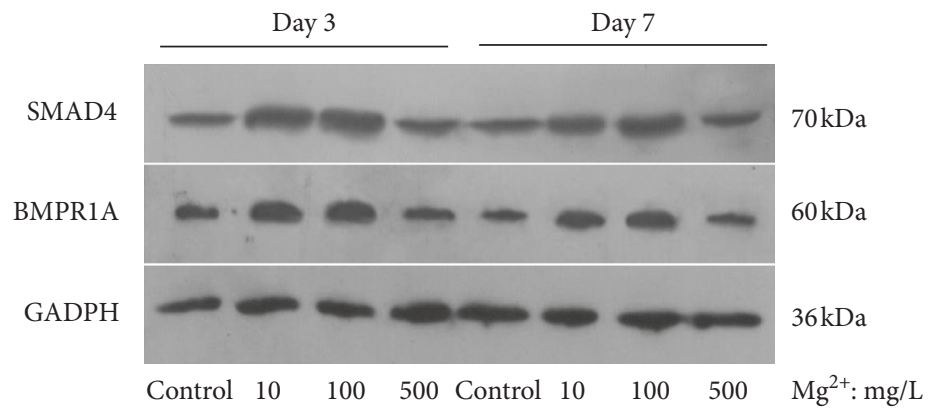

SMAD4

BMPR1A
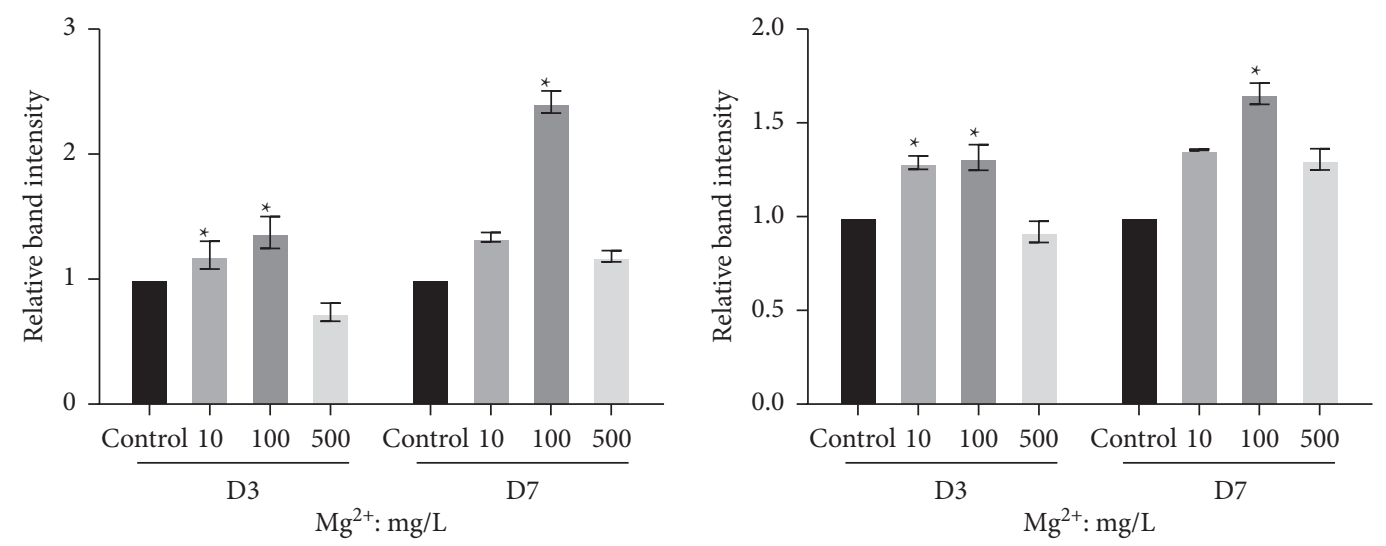

(b)

FIgURE 7: Activation of the BMP/SMAD signaling pathway in BMSCs stimulated with the Mg ions/RAW264.7 cells-conditioned media. (a) Gene expressions of the BMP/SMAD pathway markers SMAD1, SMAD4, SMAD5, and BMPR1A were demonstrated by RT-PCR. (b) Protein expressions of SMAD4 and BMPR1A were examined by western blot. ${ }^{*} P<0.05$, compared to the control group. 
cytokine production in monocytes by increasing $\mathrm{I} \kappa \mathrm{B}-\alpha$ levels and downregulating NF- $\kappa$ B p65 levels [18]. However, in our study, protein expression of NF- $\kappa \mathrm{B}$ p 65 showed no alteration in the $\mathrm{Mg}$ ion groups. Hence, we inferred that $\mathrm{Mg}$ ions might inhibit other components in the NF- $\kappa \mathrm{B}$ pathway in macrophages, such as p50 or p52. This discrepancy might be due to the diverse inflammatory cell types and different experimental conditions.

Subsequently, we sought to clarify whether the modification of macrophages by $\mathrm{Mg}$ ions would influence osteogenesis of BMSCs. Therefore, Mg ions/RAW264.7 cellconditioned media were utilized for osteogenic differentiation of BMSCs.

Importantly, RUNX2 is a key transcription factor of osteoblast differentiation [23]. ALP is a well-known marker for pre-osteoblast differentiation and osteoblast mineralization [24]. In addition, OPN and OCN are important genes in the process of mineral deposition [24]. The result showed that when stimulated with conditioned media of $100 \mathrm{mg} / \mathrm{L} \mathrm{Mg}$ ions, BMSCs resulted in a significant enhancement in ALP activity and osteogenic genes (Runx-2, ALP, OPN, and OCN), which would indicate that $\mathrm{Mg}$ ions promote osteogenesis of BMSCs through macrophage regulation.

Although microscale $\mathrm{Mg}$ ions have been shown to transit macrophages phenotype into M2, the molecular mechanisms whereby M2 macrophage influences osteogenesis are yet to be established. We hypothesized that the M2 macrophage may promote osteogenesis of BMSCs through paracrine function. Notably, a previous study reported that the M2 phenotype secretes osteoinductive and osteogenic cytokines such as BMP-2 and VEGF $[14,25]$. Among the BMP family members, BMP-2 is a potent osteoinductive agent [26-28] and VEGF is an important proangiogenic factor that binds to VEGFR and initiate angiogenic cascade [29]. In the process of bone formation, angiogenesis and osteogenesis are coupled with each other as the function of VEGF and BMP-2 has been found to be closely related and synergistic [30, 31]. Indeed, our study demonstrated that $\mathrm{Mg}$ ions upregulated the gene expression of BMP-2 and VEGF in macrophages. We inferred that the upregulation of BMP-2 might activate the BMP-2/SMAD signaling pathway in BMSCs which is the key pathway for osteogenic differentiation. In this pathway, BMP-2 binds with BMPR2 and then recruits BMPRA1 [32]. Subsequently, phosphorylation of SMAD1/5/8 is triggered, which sequentially causes dimer complex to form with SMAD4. The complexes translocate into the cell nucleus to induce transcription of the osteogenic gene, Runx2 [32]. The result however showed the activation of BMP-2/SMAD signaling in BMSCs as demonstrated by the upregulation of SMAD4 and BMPR1A at both gene and protein levels. Therefore, it is reasonable to infer that microscale $\mathrm{Mg}$ ions trigger the phenotype switches of macrophages into M2 by inhibiting the TLR-NF- $\kappa \mathrm{B}$ signaling pathway and, as a result, causes the upregulation of anti-inflammatory cytokines (IL-10 and IL-1ra). Furthermore, the microscale $\mathrm{Mg}$ ions stimulate macrophages to upregulate VEGF and BMP-2 expression, which activate the BMP-2 pathway in BMSCs, thereby enhancing osteogenic differentiation of stem cells. The present study proposed that manipulating $\mathrm{Mg}$ concentration in bone biomaterial could regulate the immune environment that positively influences osteogenesis and avoids the destructive inflammatory reaction caused by the $\mathrm{Mg}$-based biomaterial.

Apart from secretion of VEGF and BMP-2, excessive M2 macrophages have been reported to secrete fibrous agents, such as TGF- $\beta$ s, resulting in pathological fibrosis, formation of scar tissue, or delayed wound healing $[14,25,33]$. TGF- $\beta 1$ is a potent cytokine to promote fibroblast proliferation [34], and TGF- $\beta 3$ induces the synthesis of extracellular matrix (ECM) protein, such as type I collagen, fibronectin, proteoglycans, and laminin [35]. In this study, we found the downregulation of TGF- $\beta 3$ in $\mathrm{Mg}$ ion groups, which indicated that maybe stimulating macrophages with microscale $\mathrm{Mg}$ ions could not induce pathological fibrosis.

\section{Conclusions}

In summary, controlling the releasing concentration of $\mathrm{Mg}$ ions (approximately $100 \mathrm{mg} / \mathrm{L}$ ) conquers the detrimental osteoimmunomodulatory properties of Mg-based biomaterials, causing them to be more favorable towards osteogenesis of BMSCs. Specifically, microscale Mg ions induced M2 macrophage phenotype switches and produced an anti-inflammatory environment most likely through the inhibition of the TLR-NF- $\kappa \mathrm{B}$ signaling pathway. Microscale $\mathrm{Mg}$ ions stimulate macrophage expression of BMP-2 and activate the BMP-2 signaling pathway in BMSCs, thereby enhancing osteogenic differentiation. Therefore, manipulating the concentration of $\mathrm{Mg}$ ions in $\mathrm{Mg}$-based bone scaffolds endows biomaterials with favorable osteoimmunomodulatory properties. The present study provides fundamental evidence and proposes novel strategies for the development or modification of advanced Mg-based bone biomaterials using stem cells.

\section{Data Availability}

The data used to support the findings of this study are available from the corresponding author upon request.

\section{Conflicts of Interest}

The authors declare that there are no conflicts of interest regarding the publication of this paper.

\section{Acknowledgments}

This work was supported by Key Programs for Young Talents in Sun Yat-sen University (grant number 2015ykzd14) China; Medical Research Grant of Guangdong Province (grant number A2017057); Science and Technology Program of Guangzhou (grant number 201904010051), China; Young Talent Program of Sun Yat-Sen University (grant number 19ykpy85), China; and Nature Science 
Foundation of Guangdong Province (grant number 2019A1515011312), China.

\section{References}

[1] S. Franz, S. Rammelt, D. Scharnweber, and J. C. Simon, "Immune responses to implants-a review of the implications for the design of immunomodulatory biomaterials," Biomaterials, vol. 32, no. 28, pp. 6692-6709, 2011.

[2] H. Takayanagi, "Osteoimmunology: shared mechanisms and crosstalk between the immune and bone systems," Nature Reviews Immunology, vol. 7, no. 4, pp. 292-304, 2007.

[3] M. P. Staiger, A. M. Pietak, J. Huadmai, and G. Dias, "Magnesium and its alloys as orthopedic biomaterials: a review," Biomaterials, vol. 27, no. 9, pp. 1728-1734, 2006.

[4] J. Wang, J. Tang, P. Zhang, Y. Li, Y. Lai, and L. Qin, "Surface modification of magnesium alloys developed for bioabsorbable orthopedic implants: a general review," Journal of Biomedical Materials Research Part B: Applied Biomaterials, vol. 100B, no. 6, pp. 1691-1701, 2012.

[5] H. Zreiqat, C. R. Howlett, A. Zannettino et al., "Mechanisms of magnesium-stimulated adhesion of osteoblastic cells to commonly used orthopaedic implants," Journal of Biomedical Materials Research, vol. 62, no. 2, pp. 175-184, 2002.

[6] R. K. Rude, H. E. Gruber, L. Y. Wei, A. Frausto, and B. G. Mills, "Magnesium deficiency: effect on bone and mineral metabolism in the mouse," Calcified Tissue International, vol. 72, no. 1, pp. 32-41, 2003.

[7] M. H. Salimi, J. C. Heughebaert, and G. H. Nancollas, "Crystal growth of calcium phosphates in the presence of magnesium ions," Langmuir, vol. 1, pp. 119-122, 1985.

[8] S. Galli, Y. Naito, J. Karlsson et al., "Local release of magnesium from mesoporous $\mathrm{TiO}_{2}$ coatings stimulates the penimplant expression of osteogenic markers and improves osteoconductivity in vivo," Acta Biomaterialia, vol. 10, pp. 5193-5201, 2014.

[9] Z. T. Chen, X. L. Mao, L. L. Tan et al., "Osteoimmunomodulatory properties of magnesium scaffolds coated with betatricalcium phosphate," Biomaterials, vol. 35, no. 30 , pp. 8553-8565, 2014.

[10] M. K. Chang, L. J. Raggatt, K. A. Alexander et al., "Osteal tissue macrophages are intercalated throughout human and mouse bone lining tissues and regulate osteoblast function in vitro and in vivo," Journal of Immunology, vol. 181, no. 2, pp. 1232-1244, 2008.

[11] A. R. Pettit, M. K. Chang, D. A. Hume, and L.-J. Raggatt, "Osteal macrophages: a new twist on coupling during bone dynamics," Bone, vol. 43, no. 6, pp. 976-982, 2008.

[12] C. D. Mills, K. Kincaid, J. M. Alt, M. J. Heilman, and A. M. Hill, "M-1/M-2 macrophages and the Th1/Th2 paradigm," The Journal of Immunology, vol. 164, no. 12, pp. 6166-6173, 2000.

[13] D. M. Mosser and J. P. Edwards, "Exploring the full spectrum of macrophage activation," Nature Reviews Immunology, vol. 8, no. 12, pp. 958-969, 2008.

[14] C. M. Champagne, J. Takebe, S. Offenbacher, and L. F. Cooper, "Macrophage cell lines produce osteoinductive signals that include bone morphogenetic protein-2," Bone, vol. 30, no. 1, pp. 26-31, 2002.

[15] S. M. Wahl, N. McCARTNEY-FRANCIS, J. B. Allen, E. B. Dougherty, and S. F. Dougherty, "Macrophage production of TGF- $\beta$ and regulation by TGF- $\beta$," Annals of the New York Academy of Sciences, vol. 593, no. 1 Transforming, pp. 188-196, 1990.
[16] B. N. Brown, B. D. Ratner, S. B. Goodman, S. Amar, and S. F. Badylak, "Macrophage polarization: an opportunity for improved outcomes in biomaterials and regenerative medicine," Biomaterials, vol. 33, no. 15, pp. 3792-3802, 2012.

[17] F. Geng, L. L. Tan, X. X. Jin, J. Y. Yang, and K. Yang, "The preparation, cytocompatibility, and in vitro biodegradation study of pure $\beta$-TCP on magnesium," Journal of Materials Science: Materials in Medicine, vol. 20, no. 5, pp. 1149-1157, 2009.

[18] J. Sugimoto, A. M. Romani, A. M. Valentin-Torres et al., "Magnesium decreases inflammatory cytokine production: a novel innate immunomodulatory mechanism," The Journal of Immunology, vol. 188, no. 12, pp. 6338-6346, 2012.

[19] J. I. Pearl, T. Ma, A. R. Irani et al., "Role of the Toll-like receptor pathway in the recognition of orthopedic implant wear-debris particles," Biomaterials, vol. 32, no. 24, pp. 5535-5542, 2011.

[20] T. Kawai and S. Akira, "The role of pattern-recognition receptors in innate immunity: update on Toll-like receptors," Nature Immunology, vol. 11, no. 5, pp. 373-384, 2010.

[21] H. Zhou, K. Zhao, W. Li et al., "The interactions between pristine graphene and macrophages and the production of cytokines/chemokines via TLR- and NF- $\kappa$ B-related signaling pathways," Biomaterials, vol. 33, no. 29, pp. 6933-6942, 2012.

[22] J. Napetschnig and $\mathrm{H}$. Wu, "Molecular basis of NF- $\kappa \mathrm{B}$ signaling," Annual Review of Biophysics, vol. 42, no. 1 , pp. 443-468, 2013.

[23] T. M. Liu and E. H. Lee, "Transcriptional regulatory cascades in runx2-dependent bone development," Tissue Engineering Part B: Reviews, vol. 19, no. 3, pp. 254-263, 2013.

[24] T. Komori, "Regulation of osteoblast differentiation by transcription factors," Journal of Cellular Biochemistry, vol. 99, no. 5, pp. 1233-1239, 2006.

[25] D. O. Freytes, J. W. Kang, I. Marcos-Campos, and G. VunjakNovakovic, "Macrophages modulate the viability and growth of human mesenchymal stem cells," Journal of Cellular Biochemistry, vol. 114, no. 1, pp. 220-229, 2013.

[26] M. V. Bais, N. Wigner, M. Young et al., "BMP2 is essential for post natal osteogenesis but not for recruitment of osteogenic stem cells," Bone, vol. 45, no. 2, pp. 254-266, 2009.

[27] O. Fromigué, P. J. Marie, and A. Lomri, "Bone morphogenetic protein-2 and transforming growth factor- $\beta 2$ interact to modulate human bone marrow stromal cell proliferation and differentiation," Journal of Cellular Biochemistry, vol. 68, no. 4, pp. 411-426, 1998.

[28] T. Takiguchi, M. Kobayashi, R. Suzuki et al., "Recombinant human bone morphogenetic protein-2 stimulates osteoblast differentiation and suppresses matrix metalloproteinase-1 production in human bone cells isolated from mandibulae," Journal of Periodontal Research, vol. 33, no. 8, pp. 476-485, 1998.

[29] A. Hoeben, B. Landuyt, M. S. Highley, H. Wildiers, A. T. Van Oosterom, and E. A. De Bruijn, "Vascular endothelial growth factor and angiogenesis," Pharmacological Reviews, vol. 56, no. 4, pp. 549-580, 2004.

[30] F. Zhang, T. Qiu, X. Wu et al., "Sustained BMP signaling in osteoblasts stimulates bone formation by promoting angiogenesis and osteoblast differentiation," Journal of Bone and Mineral Research, vol. 24, no. 7, pp. 1224-1233, 2009.

[31] H. Peng, V. Wright, A. Usas et al., "Synergistic enhancement of bone formation and healing by stem cell-expressed VEGF and bone morphogenetic protein-4," Journal of Clinical Investigation, vol. 110, no. 6, pp. 751-759, 2002. 
[32] J. W. Lowery, D. Pazin, G. Intini et al., "The role of BMP2 signaling in the skeleton," Critical Reviews in Eukaryotic Gene Expression, vol. 21, no. 2, pp. 177-185, 2011.

[33] B. N. Brown and S. F. Badylak, "Expanded applications, shifting paradigms and an improved understanding of hostbiomaterial interactions," Acta Biomaterialia, vol. 9, no. 2, pp. 4948-4955, 2013.

[34] L. Xiao, Y. Du, Y. Shen et al., "TGF-beta 1 induced fibroblast proliferation is mediated by the FGF-2/ERK pathway," Frontiers in Bioscience, vol. 17, no. 7, pp. 2667-2675, 2012.

[35] J. M. Norian, M. Malik, C. Y. Parker et al., "Transforming growth factor $\beta 3$ regulates the versican variants in the extracellular matrix-rich uterine leiomyomas," Reproductive Sciences, vol. 16, no. 12, pp. 1153-1164, 2009. 


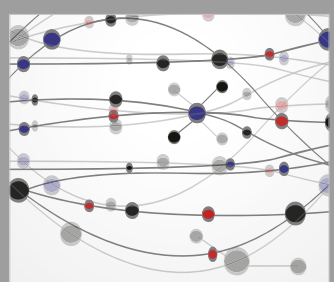

The Scientific World Journal
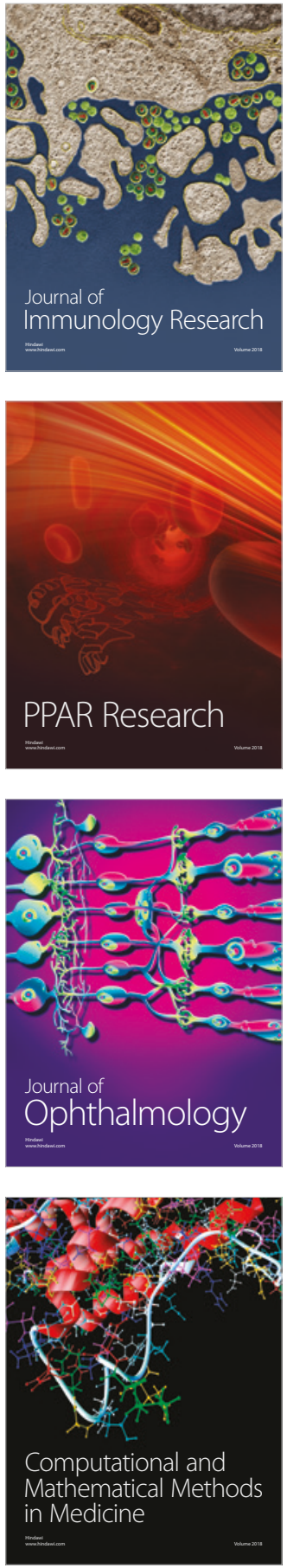

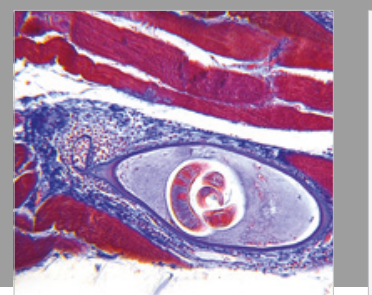

Gastroenterology Research and Practice

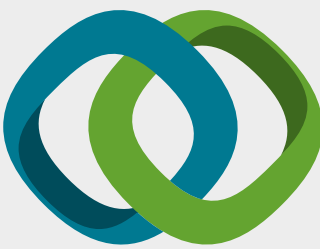

\section{Hindawi}

Submit your manuscripts at

www.hindawi.com
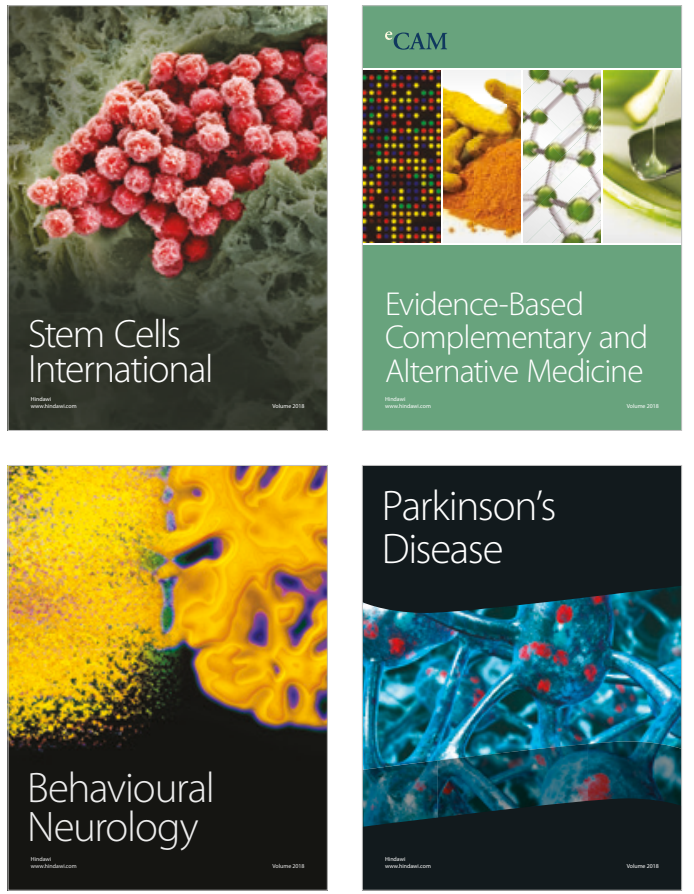

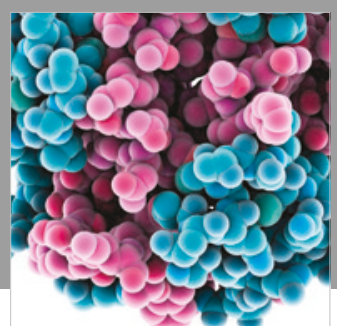

ournal of

Diabetes Research

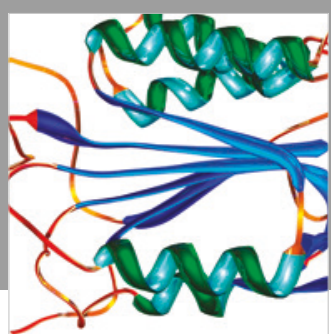

Disease Markers
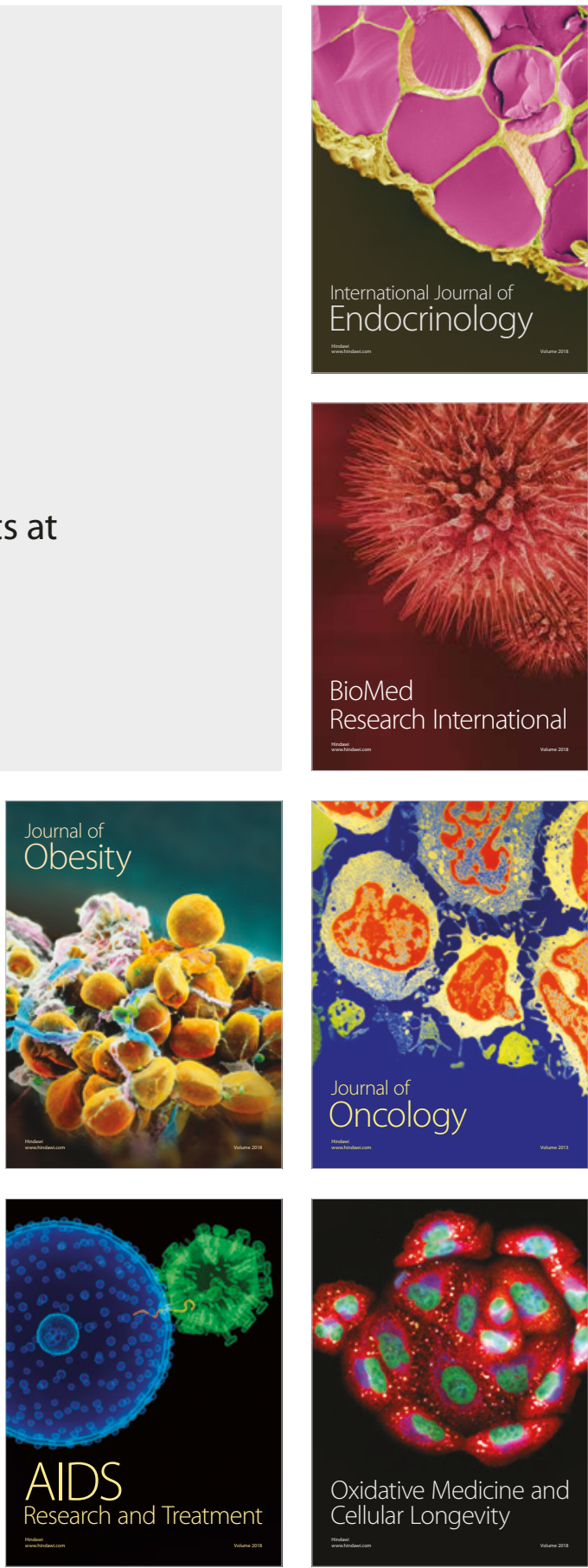